\title{
Kropp i bevegelse i bildeboka Känner du Pippi Långstrump?
}

http://urn.kb.se/resolve?urn=urn:nbn:se:sbi-26

Citation: Nordic Journal of ChildLit Aesthetics, Vol. 2, 2011 DOI: 10.3402/

blft.v2i0.5831

Abstract: In Astrid Lindgren's authorship, there are many bodies in motion, and one of her most movable and energetic characters is Pippi Longstocking. In the illustrated novels about Pippi (Lindgren and Nyman 1945, 1946, and 1948) there are relatively few pictures, and as a result, Lindgren's words carry most of the story. In the novels, her words have a greater functional load (Kress 2003, 46 ) than Nyman's pictures. Naturally then, the words convey most of the information about Pippi and the other characters' movements. But how does the portrayal of bodies in motion change when Pippi is portrayed in picturebooks where the pictures have a lot more space, ie, a greater functional load than in the illustrated novels? The aim of this article is to study bodies in motion in Astrid Lindgren's and Ingrid Nyman's picturebook Do you Know Pippi Longstocking? (1947). My main focus will be how words and illustrations - together and separately - provide the reader with information about Pippi's movements in this picturebook.

Keywords: Astrid Lindgren, Ingrid Nyman, picturebooks, bodies in motion, word-picture-relationship, iconotext (word-picture-readerrelationship), modal affordance, functional load.

"Barnen i Astrid Lindgrens böcker springer jämt", skriver den
svenske lindgrenforskeren Vivi Edström i boka Det svänger om Astrid
(2007, 39). Edström siterer her sine barnebarns opplevelse av Lind-
grens bøker. Det er ikke overraskende at disse lesende barna har fått
et slikt inntrykk, for i dette fiksjonsuniverset er det mye bevegelse.
En del bevegelse er forbundet med lek og fart og moro - som når
Emil og lille Ida leker "Sicken blås [...] en springlek som Emil hade
hittat på" og løper 88 runder rundt i huset på Katthult (Lindgren og
Berg 2006 [1966], 25). Noen ganger er bevegelse en nødvendig del av
det å forflytte seg fra ett sted til et annet - som når bullerbybarna 
gang på gang går den lange, men ubekymrede veien til og fra skolen (Lindgren og Nyman 1947, 1949 og 1952), eller når Rasmus legger ut på sin langt mer strabasiøse ferd med det doble målet om å komme seg vekk fra barnehjemmet og å finne seg en familie (Lindgren og Palmquist 1956). Andre bevegelser kan leses som et uttrykk for generell livsglede, som når Ronja strekker armene mot himmelen idet hun jubler ut sitt vårskrik (Lindgren og Wikland 1981, 236). Men atter andre bevegelser er knyttet til dramatiske hendelser eller eksistensielle spørsmål, og i disse situasjonene holder det ikke med små bevegelser. Da er det store, vågale og av og til sublime bevegelser som gjelder - som for eksempel brødrene Lejonhjärtas hopp ut fra det brennende huset i begynnelsen av Bröderna Lejonhjärta og spranget fra Nangijala til Nangilima i romanens sluttscene (Lindgren og Wikland 1973, 228).

I denne artikkelen vil jeg fokusere på kropp i bevegelse. I de mange illustrerte barnebøkene i Lindgrens forfatterskap er det ordene som bærer det aller meste av fortellinga, som har størst funksjonell tyngde (functional load, Kress 2003, 46). Naturlig nok er det dermed også ordene som formidler mest informasjon om de ulike karakterenes bevegelser. Men hvordan arter dette seg i bildebokmediet der bildene får langt større plass, altså større funksjonell tyngde, enn i de illustrerte bøkene? For i bildebøker utgjør ord og bilder et samspill som i lesesituasjonen realiseres til en ikonotekst (Hallberg 1982, 165). Utgangspunktet for denne studien er den første bildeboka om Pippi, nemlig Astrid Lindgrens og Ingrid Nymans Känner du Pippi Långstrump? fra 1947. I det følgende vil jeg studere hvordan ord og bilder sammen og hver for seg formidler informasjon om Pippis bevegelser i denne bildeboka.

\section{Formidling av bevegelse i bildebøker}

Ord og bilder har ulik modal affordans (modal affordance, Jewitt og Kress 2003, 14), altså ulike muligheter og begrensninger når det gjelder hva og på hvilken måte de kan formidle noe til en leser. Når det gjelder informasjon om bevegelse, kan ord uttrykke dette på uendelig mange måter både når det gjelder bevegelser i fortid, nåtid, og framtid. Et av de språklige virkemidlene som er hyppigst brukt i Lindgrens forfatterskap, er bevegelsesverb - og gjerne da bevegelsesverb som indikerer raske eller fysisk krevende bevegelser: Karakterene "springer", "skuttar", "hoppar", "klättrar", "kliver", "balanserar" og "flyger" - bare for å nevne noe. Ord kan også mer indirekte gi en opplevelse av bevegelse ved å for eksempel gi informasjon om sceneskift der vi forstår at personene har forflyttet seg fra 
ett sted til et annet. Jo hyppigere disse sceneskiftene skjer, jo større opplevelse får leseren av bevegelse i tid og rom.

Når det gjelder bilder i bildebøker, så mangler de muligheten til å avbilde bevegelse direkte. Bildene i bildebøker er statiske. Bildebøker er imidlertid sekvensielle og som regel også narrative, de har som oftest til hensikt å vise bevegelse i tid og rom i løpet av handlingas gang (se også Nikolajeva 2000, 201f og Nikolajeva og Scott 2001, 139f). Tid og rom er uløselig knyttet til hverandre (jf. kronotop, Bakhtin 1981 [1937-38], 84), og i bildebøker blir det veldig tydelig at tid er noe som kan uttrykkes mest presis ved hjelp av ord, mens rom er noe som kan uttrykkes mest presis ved hjelp av bilder (jf. modal affordans ovenfor). I bildebøker kan de to modalitetene skrift og bilde utfylle hverandres muligheter og begrensinger i et gjensidig samspill og i samarbeid med leseren som realiserer ikonoteksten i lesesituasjonen.

Bildebokillustratører opererer med mange ulike visuelle virkemidler for å gi en opplevelse av at karakterene og deres kropper beveger seg. Noen vanlige virkemidler er for eksempel intendert utydelighet (blurs), bevegelseslinjer (motion lines eller action lines), perspektivforvrengninger, og uavslutta hendelser (se også Druker 2008, 32f, McCloud 1993, 107f, Nikolajeva 2000, 202, og Nikolajeva og Scott 2001, 139). I nyere bildebøker ser vi ofte også bruk av simultansuksesjon (simultaneous succession, Nikolajeva og Scott 2001, 140f), det vil si "a sequence of images, most often of a figure, depicting moments that are disjunctive in time but perceived as belonging together, in an unequivocal order" (ibid.). Simultansuksesjon i et bilde har tilnærma samme effekt som en verbal oppramsing av én og samme persons handlinger. På samme måte som simultansuksesjon kan formidle bevegelse ved hjelp av gjentakelser innenfor ett og samme bilde, kan bildesekvenser formidle bevegelser innenfor ett og samme oppslag. En bildesekvens innebærer altså to eller flere bilder på ett oppslag, der bildene for eksempel viser én person i ulike situasjoner. På denne måten formidler bildesekvensen informasjon om bevegelse over en viss tid (Nikolajeva 2000, 205, Nikolajeva og Scott 2001, 146).

\section{Pippi - en inkarnasjon av bevegelse?}

"Pippi Långstrump är en inkarnation av rörelse", skriver Vivi Edström $(2007,45)$. Hun baserer først og fremst sin uttalelse på framstillinga av Pippi i de tre illustrerte barnebøkene (Lindgren og Nyman 1945,1946 og 1948), samt på framstillinga av Pippi-karakteren i Ur-Pippi (Lindgren 2007 [1944]) der Edström mener at Pippi har "drag av det arketypiska monstruösa barnet, det oövervinnerliga, 
med gigantiska krafter" (Edström 2007, 46). Det er ikke vanskelig å si seg helt eller delvis enig med Edström i denne karakteristikken av Pippi, men hvordan framstilles Pippi i bildeboka Känner du Pippi Långstrump? - er hun også der en inkarnasjon av bevegelse, en person med tilnærma uendelige mengder "spring i bena"?

\section{En kort presentasjon av bildeboka Känner du Pippi Långstrump?}

Handlinga i bildeboka Känner du Pippi Långstrump? (1947) vil være kjent for alle som har lest Lindgrens gjennombruddsbok Pippi Långstrump fra 1945, for ordene i bildeboka er i all hovedsak en redigert og omskrevet versjon av fem kapitler i denne boka (kap. 1, 2, 7, 8 og 11). Illustrasjonene i bildeboka er nylaga av Ingrid Nyman, og det er først og fremst Pippi, Tommy og Annika, Villa Villekulla, Pippis hest og Herr Nilsson vi kjenner igjen fra de åtte svart-hvitt-bildene i den illustrerte barneboka. Utover dette har Nyman valgt ut andre scener og motiver i bildeboka enn i den illustrerte barneboka. Mens den illustrerte barneboka har fargebilde på forsiden og åtte svarthvitt-bilder i løpet av de 174 sidene, har bildeboka totalt 32 fargebilder.

Det overordna prosjektet i Känner du Pippi Långstrump? er tilsynelatende at leseren skal få et gjensyn med eller også bli kjent med personen Pippi for første gang (jf. boktittelen). Måten dette gjøres på er blant annet ved å informere om - gjennom både ord og bilder

- Pippis egenskaper og særegenheter i mange ulike situasjoner og på mange forskjellige steder. Vi møter Pippi i ulike settinger både utenfor og inne i Villa Villekulla: Hun flytter inn, treffer Tommy og Annika, lager pannekaker til sine nye venner, baker pepperkaker på kjøkkengulvet, hogger ved, feier pipa, er "sakletare", ordner opp med tyvene Blom og Dunderkarlsson, feirer fødselsdag, og leker "Inte Stöta Golvet" på kjøkkenet - bare for å nevne noe. Og innimellom dette går hun på sirkus. På sirkuset nøyer hun seg ikke med rollen som publikummer. I stedet beveger hun seg fra dans på line, til hesteryggen, til kamp med Starke Adolf. Alle disse situasjonene og bevegelsene kjenner vi igjen fra Pippi Långstrump. Den vesentligste forskjellen er at den visualiseringa som leseren av den illustrerte barneboka i stor grad må stå for selv, langt på vei er foretatt av illustratøren i bildeboka. Alle Pippis forflytninger gjennom den relativt korte bildeboka tyder på at Pippi har høy bevegelseshastighet i tid og rom.

Känner du Pippi Långstrump? har et stort, stående format $(28,5 \times 22$ $\mathrm{cm}$.). Det er ofte vanlig å velge et liggende format til bildebøker som har til hensikt å gjengi bevegelser og rom, siden den lange hori- 


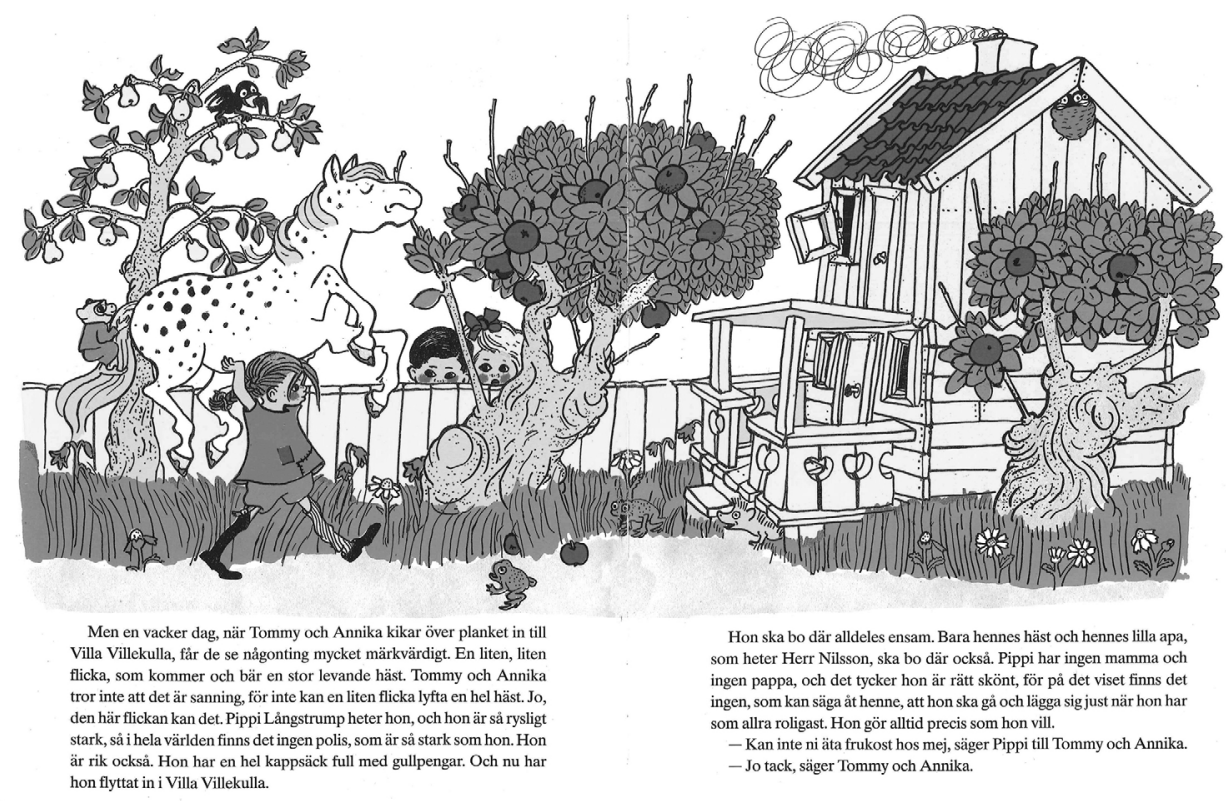

III. I ( ) Astrid Lindgren og Ingrid Nyman (ill.). Känner du Pippi Långstrump? Stockholm: Rabén \& Sjögren, 1947, side 8-9. Eftertryck förbjudes och att teckningarna återges med tillstånd av Saltkråkan $\mathrm{AB}, \mathrm{SE}-\mathrm{I8|} 33$ Lidingö.

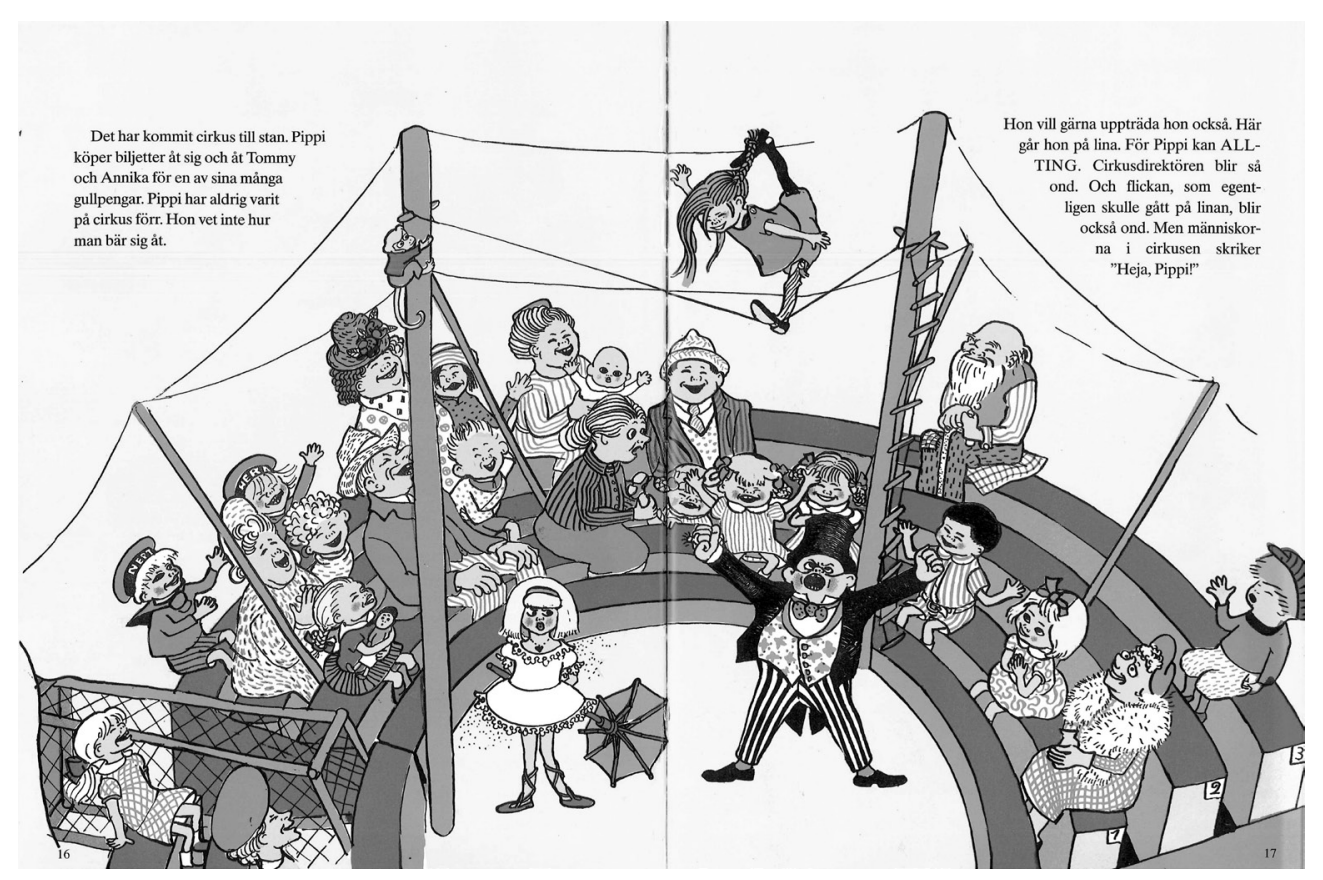

III. 2 @ Astrid Lindgren og Ingrid Nyman (ill.). Känner du Pippi Långstrump? Stockholm: Rabén \& Sjögren, 1947, side 16-17. Eftertryck förbjudes och att teckningarna återges med tillstånd av Saltkråkan $\mathrm{AB}, \mathrm{SE}-\mathrm{I8I} 33$ Lidingö. 


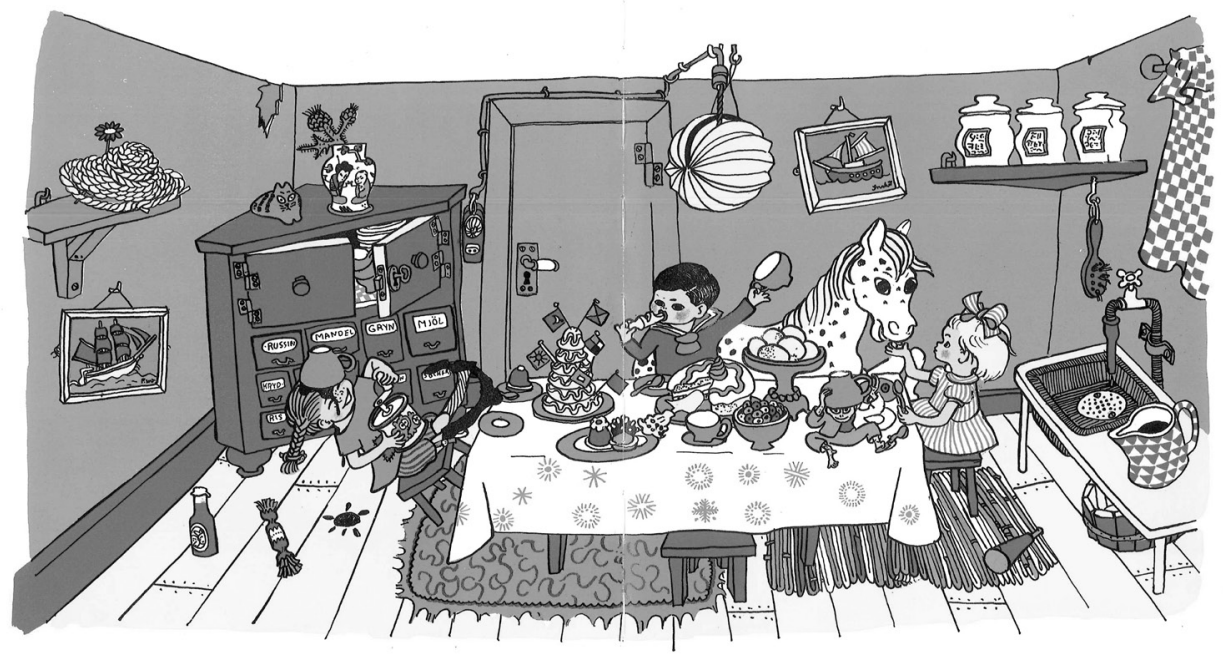

III. 3 ( ) Astrid Lindgren og Ingrid Nyman (ill.). Känner du Pippi Långstrump? Stockholm: Rabén \& Sjögren, 1947, side 24-25. Eftertryck förbjudes och att teckningarna återges med tillstånd av Saltkråkan AB, SE-18I 33 Lidingö.

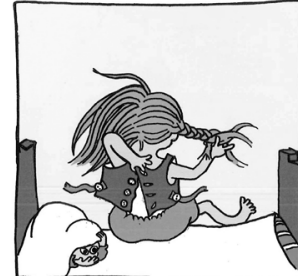

Pippi kan fläta hăret och knäppa livstycket på samma gång. Det är inte många som kan det.

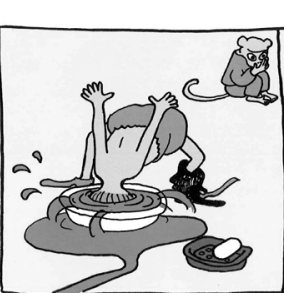

När hon tvättar sig, doppar hon ner hela huvet $\mathrm{i}$ tvättfatet. Hon tycker sả mycket om att fầ vatten $\mathrm{i}$ örona.

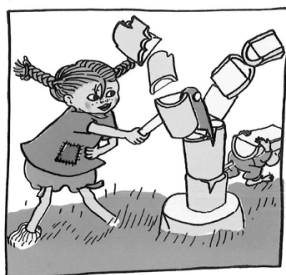

När hon hugger ved, hugger hon aldrig mindre än fem vedträn $i$ taget.

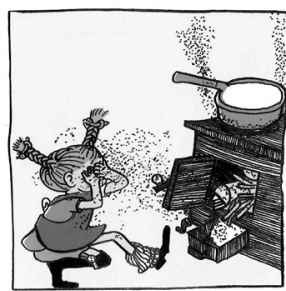

Usch, vad spisen ryker in! Pippi måste opp på taket och sota skorstenen

Hon gör ALLTING själv.

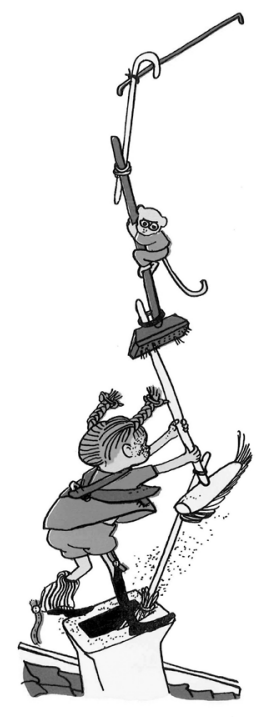

III. 4 (c) Astrid Lindgren og Ingrid Nyman (ill.). Känner du Pippi Långstrump? Stockholm: Rabén \& Sjögren, 1947, side 12-13. Eftertryck förbjudes och att teckningarna återges med tillstånd av Saltkråkan AB, SE-I8I 33 Lidingö. 
sontale aksen gir leseren en opplevelse av at tiden går (Nikolajeva og Scott 2001, 242). Känner du Pippi Långstrump? er imidlertid et godt eksempel på at også stående format kan formidle bevegelse på en effektiv måte. For det første gir et stående format god plass til bruk av bildesekvenser, altså flere mindre bilder som for eksempel kan formidle bevegelse ved å vise én og samme person i ulike situasjoner. For det andre har ei oppslått bok i stort, stående format mye handlingsrom både langs den horisontale og den vertikale aksen. I Känner du Pippi Långstrump? er det mange oppslag med flere mindre bilder (se f.eks. ill. 4), men i tillegg er det tre viktige oppslag der ett og samme bilde strekker seg over ei dobbeltside: da Pippi flytter inn i Villa Villekulla (ill. 1), da Pippi balanserer på line på sirkuset (ill. 2), og da Pippi feirer fødselsdag (ill. 3). Den store plassen bildene får på disse tre oppslagene understreker viktigheten av disse tre scenene i bildeboka.

Den første scenen (ill. 1) er det viktige førstemøtet mellom Pippi, Tommy og Annika, deretter er sirkusscenen den lengste turen som barna foretar sammen "ut i verden" i denne boka (ill. 2), og når vi nærmer oss slutten av boka understreker scenen rundt fødselsdagsbordet (ill. 3) at forholdet mellom Pippi, Tommy og Annika har utviklet seg til en relasjon som nå er etablert og antakelig vil vare ved.

\section{Spatiale forflytninger, sceneskift, iterativ frekvens og redundans}

De 32 bildene i boka rommer tilnærma like mange spatiale forflytninger, og antallet sceneskift i boka totalt sett er langt høyere på grunn av for eksempel tilbakeblikk og frampek i den verbale framstillinga, eller på grunn av iterativ frekvens, der vi blir presentert for ulike hendelser som vi forstår skjer gjentatte ganger (Nikolajeva 2000, 203). Et eksempel på iterativ frekvens finner vi på oppslag fire (ill. 4). Ord og bilder på dette oppslaget inneholder informasjon om hvordan Pippi fletter håret mens hun kler på seg, hvordan hun spiser, vasker seg, vasker gulvet, hogger ved, ordner komfyren og feier pipa. "Hon gör ALLTING själv", står det (s. 13, ill. 4), og i dette ligger det at hun gjør alt selv alltid. Illustrasjonenes plassering legger også opp til at vi kan lese bildene i en tilnærma sirkulær bevegelse som innbyr til gjentakelse. Dette er gjøremål - og bevegelser - som Pippi gjentar om og om igjen. Dette oppslaget er også et eksempel på at redundans i ord og bilde kan skape et inntrykk av mer bevegelse enn om hver av handlingene Pippi foretar seg bare ble formidlet ved hjelp av én modalitet. 


\section{Variert perspektivbruk og perspektivforvrengninger}

I Känner du Pippi Långstrump? har som sagt ordene mindre funksjonell tyngde enn i den illustrerte boka Pippi Långstrump. Dette innebærer blant annet at selv om mange av Pippis bevegelser beskrives med ord eller med både ord og bilder - for eksempel at hun "bär en stor levande hest" (ill. 1), eller at hun "kastar" ei pannekake "högt upp i luften" (ill. 5) - så formidles svært mange av Pippis bevegelser bare gjennom bildene. I tillegg til det som allerede er nevnt, bruker Ingrid Nyman mange effektive virkemidler for å framstille Pippi som en "inkarnation av rörelse", blant annet ved å variere perspektivbruken og ved å kombinere flere perspektiver i ett og samme bilde slik at det blir en slags perspektivforvrengning. I underkant av $60 \%$ av bildene er tegnet i normalperspektiv, mens resten av bildene er undervinkla eller overvinkla i større eller mindre grad, eller også en kombinasjon av normalperspektiv og under- eller overvinkling. Variasjon i perspektivbruk gjennom boka skaper dynamikk og gir et generelt inntrykk av bevegelse, men det er særlig de bildene som har en slags perspektivforvrengning som gir størst inntrykk av bevegelse. Ett eksempel er der Pippi er på sirkus og balanserer på line (ill. 2). Her ser vi publikum i et fugleperspektiv, mens vi ser Pippi i normalperspektiv. Én effekt av dette er at Pippi og hennes bevegelser blir tydeligere for oss og nærmere oss som lesere enn om for eksempel hele scenen hadde blitt sett fra et fugleperspektiv.

\section{Uavslutta hendelser og bruk av detaljer}

Et annet effektivt virkemiddel som brukes i bildene, er at Pippi så godt som alltid er framstilt midt $i$ en uavslutta hendelse. Hun har nesten alltid ett bein i lufta eller en arm eller to ut fra kroppen (f.eks. ill. 1, 2 og 4), og den eneste gangen hun ikke har dette (i avslutningsscenen der hun står stille og lener seg mot porten), så står i hvert fall flettene hennes ut fra hodet og opphever tyngdekraften. I tillegg ser vi flere ganger at kjoleknappen bak på kjolen er åpen, eller at minst én strømpe har glidd ned rundt ankelen (f.eks. ill. 4 og 5). Begge deler indikerer at Pippi har beveget seg så voldsomt at klærne har kommet i uorden.

I illustrasjonene finner vi dessuten mange små bildeelementer som ikke nevnes i den verbale delen av fortellinga, men som indikerer Pippis tidligere eller potensielle bevegelser. På bildet på venstre side av oppslag tre (ill. 5) ser vi for eksempel at det ligger tre hele egg på gulvet, så kanskje Pippi skal lage mer pannekakerøre? 

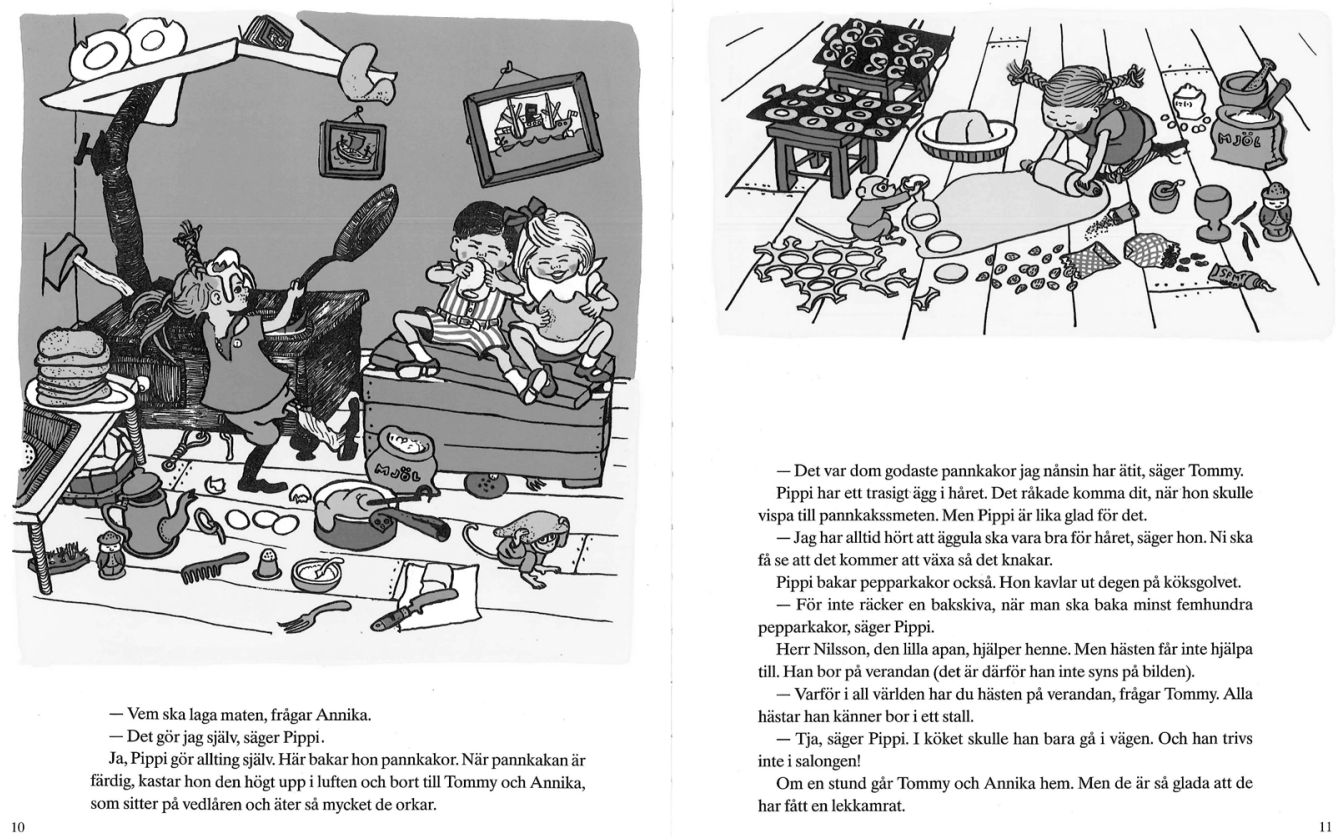

\footnotetext{
- Det var dom godaste pannkakor jag nảnsin har ätit, säger Tommy. Pippi har ett trasigt ägg i hảret. Det rảkade komma dit, när hon skulle vispa till pannkakssmeten. Men Pippi är lika glad för det.

- Jag har alltid hört att äggula ska vara bra för håret, säger hon. Ni ska få se att det kommer att växa så det knakar

Pippi bakar pepparkakor också. Hon kavlar ut degen pả köksgolvet.

- För inte räcker en bakskiva, när man ska baka minst femhundra pepparkakor, säger Pippi.

Herr Nilsson, den lilla apan, hjälper henne. Men hästen fảr inte hjälpa till. Han bor på verandan (det är därför han inte syns på bilden).

- Varför i all världen har du hästen på verandan, frågar Tommy. Alla hästar han känner bor i ett stall.

- Tja, säger Pippi. I köket skulle han bara gả i vägen. Och han trivs inte i salongen!

Om en stund går Tommy och Annika hem. Men de är să glada att de har fått en lekkamrat.
}

III. 5 (C) Astrid Lindgren og Ingrid Nyman (ill.). Känner du Pippi Långstrump? Stockholm: Rabén \& Sjögren, 1947, side 10-II. Eftertryck förbjudes och att teckningarna återges med tillstånd av Saltkråkan AB, SE-I8I 33 Lidingö.

Og av de tre pannekakene som Tommy og Annika og Herr Nilsson holder og av stabelen med pannekaker som står på bordet, skjønner vi at hun har kastet minst ti pannekaker i lufta allerede. De sprukne tallerkenene over komfyren vitner om tidligere krumspring, og det samme gjør øksa som står i veggen. Øksa ser vi igjen når vi blar om til neste oppslag (ill. 4), og dermed forstår vi at Pippi - uvisst når har dratt øksa ut av kjøkkenveggen og beveget seg ut i hagen med øksa for å hogge ved - og "aldrig mindre än fem vedträn i taget" (s. 13). Detaljen med øksa utgjør altså en ørliten parallellhistorie som vitner om Pippis bevegelser og som bare er til stede i bildene.

En noe mer omfattende parallellhistorie får vi dersom vi velger å følge Herr Nilsson gjennom boka. Nå er ikke Herr Nilsson en detalj i vanlig forstand - verken i bildene eller i den verbale delen av fortellinga - men som bildeelement er han nokså liten å se til, og han får heller ikke mye plass i Lindgrens tekst. Gjennom ordene i boka får vi vite navnet hans, Herr Nilsson (dvs. informasjon som ikke kan formidles gjennom bilder), og at han er Pippis ape. Videre får vi vite at han hjelper Pippi med å bake pepperkaker, at han sover i ei grønn dokkeseng, at han sitter på bordet under fødselsdagsselskapet, og at han vinker til Tommy og Annika når de går hjem. I bildene lever imidlertid Herr Nilsson sitt eget lille liv, og han er også mer fysisk 
aktiv enn i Lindgrens tekst. Han henger i halen til hesten, han har fått - eller kanskje tatt? - ei pannekake, han trykker ut pepperkaker med et glass, gjemmer seg under Pippis pute, drikker av et sugerør, ler av Pippi når hun vasker seg, stikker av gårde med en vedkubbe, henger fast på en av kostene Pippi bruker til å feie pipa med, erter tyvene, dypper halen sin i blekket Pippi bruker når hun skriver fødselsdagsinvitasjoner, tar en kopp på hodet, gjemmer seg under oppvaskbenken når barna leker "Inte Stöta Golvet", og roter i skuffene i Pippis kommode. På flere bilder hermer han dessuten etter Pippi, men uten å gjøre like store eller vågale bevegelser som Pippi gjør. Og tatt i betraktning at Herr Nilsson er en ape, sier dette noe om hvor bevegelig Pippi er. Herr Nilsson er nært knyttet til Pippi-karakteren, og hans mange bevegelser understreker både Pippis kroppslige bevegelser og at det skjer mye der Pippi er.

\section{Sterke farger og mønstrete overflater}

I Känner du Pippi Långstrump? møter vi for første gang Pippi i farger gjennom ei hel bok. En av de mest sentrale fargene vi som lesere forbinder med personen Pippi, er antakelig fargen på håret hennes. I Pippi Långstrump kan vi lese at: "Hennes hår hade samma färg som en morot och var flätat i två hårda flätor, som stod rätt ut" (Lindgren og Nyman 1945, 11). I bildeboka er ikke hårfargen beskrevet med ord. Dette er overlatt til illustrasjonene, og vi ser tydelig at Pippis hår er oransje. Oransje - eller gulrødt - er en farge som gir inntrykk av varme, energi og bevegelse, og den dynamikken som hårfargen utstråler understrekes av hårets fysiske bevegelser. For i bildeboka står ikke bare flettene rett ut slik Lindgren beskriver dem i Pippi Långstrump. Ved flere tilfeller står de rett opp og forsterker andre oppadgående kroppsbevegelser (f.eks. at Pippi kaster pannekaka opp i lufta, ill. 5). I samtlige bilder fra sirkusbesøket har den ene fletta løsnet, og det oransje håret flagrer løst og understreker både Pippis voldsomme bevegelser og den kaossituasjonen hun skaper i sirkusmanesjen.

I tillegg til det gulrotfargete håret, omgir Pippi seg med flere andre sterke og energiske farger som øker inntrykket av Pippi som en person i stadig bevegelse i illustrasjonene. Særlig dominerende er primærfargene gult og rødt. Villa Villekulla er et gult hus med rødt tak, alle gulvene og takene inne i huset er gule, mye av interiøret er gult eller rødt, sirkusteltet er gult og det er røde sitteflater på sirkusbenkene, Pippis undertrøye og husmorforkle er røde, og den ene strømpa hennes er gul. Riktignok er det også roligere og mindre 
dynamiske farger som får mye plass, først og fremst sekundærfargen grønt og primærfargen blått. Men disse fargene har også den effekten at de er kontrastfarger til henholdsvis rødt og oransje, og dermed er de også med på å forsterke og synliggjøre de dynamiske fargene i illustrasjonene.

Et annet virkemiddel Nyman gjør bruk av for å skape et inntrykk av bevegelse er mønstrete overflater som gjerne har den effekten at de kan "skapa rörlighet och vitalitet i bilderna" (Druker 2008, 36). Denne effekten blir særlig framtredende når den kombineres med bruk av sterke farger. Det er mange eksempler på mønstrete overflater i huset til Pippi. Veggene på soverommet har for eksempel grønne og hvite vertikale striper, noe som understreker den oppadgående og eksplosive bevegelsen i ord og bilder når Pippi "kastar" tyvene Dunderkarlsson og Blom opp på skapet i tur og orden når de prøver å stjele "kappsäcken".

\section{Kontraster}

Både Lindgren og Nyman bruker kontraster som et effektivt virkemiddel. For eksempel blir Pippis kroppslige bevegelser ytterligere forsterket av kontrasten til de mindre bevegelige personene Tommy og Annika. I den verbale delen av fortellinga blir de beskrevet som "två små rara och snälla barn" (s. 7), og før de går i Pippis fødselsdagsselskap "tar [de] på sig fina kläder och kammar sig i håret" (s. 23). Også i bildene er Tommy og Annika velstelte og velkledde, de står stille bak gjerdet og ser Pippi komme gående med lange skritt mot Villa Villekulla mens hun bærer hesten på strake armer (ill. 1), de sitter på vedkassa mens Pippi står med egg på hodet og kaster pannekaker i lufta (ill. 5), de sitter sammen med resten av publikum når de er med Pippi på sirkus (ill. 2), og de sitter nokså pent og pyntelig rundt fødselsdagsbordet - $\mathrm{i}$ hvert fall sammenliknet med Pippi, som sitter med begge beina på bordet og tipper på stolen mens hun både spiller på spilledåsen og balanserer en kopp på hodet (ill. 3).

\section{Bildesekvenser og negativt rom}

På flere oppslag i Känner du Pippi Långstrump? bruker Nyman bildesekvenser for å vise Pippis bevegelser. Ett eksempel er det allerede nevnte oppslag fire (ill. 4). På venstre side av dette oppslaget ser vi Pippi i fire ulike situasjoner. Bildene er imidlertid plassert på en slik måte at to og to bilder henger sammen og derfor minner sterkt om en simultansuksesjon - det er bare en svart strek som skiller dem. 
Også tidsmessig og tematisk kan vi finne en logisk relasjon mellom de bildene som deler én side av den svarte rammen. På de øverste bildene etterfølges hårfletting og påkledning av et måltid. Av sammenhengen kan det derfor være logisk å tenke at det er morgen og at Pippi spiser frokost. Og siden bildene henger sammen, leser vi dem gjerne slik at disse handlingene skjer rett etter hverandre uten et langt tidsavbrudd. Det samme gjelder de nederste to bildene. Vann er et tema i begge bilder, og av plasseringa kan vi få inntrykk av at det ikke går så lang tid mellom Pippis voldsomme bevegelser når hun vasker seg selv og deretter gulvet. Bildene på høyre side av oppslaget henger ikke like tett sammen. De er (i likhet med mange andre bilder i denne boka) omgitt av negativt rom, altså en helt hvit bakgrunn. Fravær av bakgrunn har i seg selv den effekten at leserens oppmerksomhet trekkes mot personene og deres handlinger (Nikolajeva 2000, 121). Pippis bevegelser når hun for eksempel hogger ved eller feier pipa blir dermed tydeligere enn om det ikke hadde vært et slikt negativt rom rundt bildene. Det repeterende i hele bildesekvensen på oppslag fire blir enda tydeligere når man ser ord og bilder i sammenheng. Lindgrens tekst er stort sett skrevet i presens, en verbform som både kan uttrykke nåtid og det som alltid gjelder, og sammen med for eksempel bruken av preposisjonen "ibland" ("Ibland skurar hon köksgolvet", 12) og konjunksjonen "när" ("När hon tvättar sig, doppar hon ner hela huvet i tvättfatet", ibid) og det ubestemte pronomenet "allting" ("Hon gör ALLTING själv", 13), forsterkes opplevelsen av at Pippi ofte eller alltid er i bevegelse, alltid på vei fra én handling til en annen.

\section{"[S]pring i bena, det är livskänsla det!”}

"Spring i bena" er en frase som går igjen mange ganger i Astrid Lindgrens forfatterskap. Noen ganger betyr det kanskje det motsatte av "trøtt", som når lille Lotta i Bråkmakargatan sier til mamma at "Jag har så mycket spring i bena. Men jag går och lägger mej ändå" (Lindgren og Wikland 1958, 92). Andre ganger står uttrykket for en mer omfattende følelse, som når Saltkråkans Malin sier til Pelle at "När du säjer att du har så mycket spring i bena, det är livskänsla det!" (Lindgren og Wikland 1964, 85).

Pippi har utvilsomt mye "spring $i$ bena" $i$ alle mulige betydninger av uttrykket. I bildeboka er det imidlertid ikke slik at ordene formidler mest informasjon om Pippis bevegelser, slik det er i de illustrerte barnebøkene. Den funksjonelle tyngden har blitt forskjøvet slik at ord og bilder sammen bærer fortellinga, og - som jeg har vist i denne 
artikkelen - er det i utstrakt grad Ingrid Nymans illustrasjoner som formidler informasjon om Pippis mange forflytninger og bevegelser og som framstiller henne som en person med en kropp i stadig bevegelse. Gjennom endring av den funksjonelle tyngden og gjennom å gi så mye plass til bildene, som har en annen modal affordans enn den verbale delen av teksten og dermed kan formidle annen informasjon enn det ord kan, blir Pippi som person framstilt noe annerledes i bildeboka enn i de illustrerte barnebøkene - også med tanke på bevegelser. Personen Pippi blir konkretisert gjennom bildene, og de kroppslige bevegelsene hennes blir mer konkrete ved at de blir visualisert.

Samtidig er det en del som går tapt i forhold til slik vi kjenner Pippi fra de illustrerte barnebøkene. Noe av det som er med på å skape liv og røre og en opplevelse av Pippi som en person som hele tiden er i bevegelse, er de mange skrønene hennes om alt fra mormors eiendommelige hushjelp, Malin (Lindgren og Nyman 1945, 133f) til de mange påståtte opplevelsene sammen med pappa Efraim og hans mannskap på de sju hav. Disse språkakrobatiske historiene understreker Pippis livfulle og verdensvante karakter, og dette er et viktig uromoment ved Pippi, slik vi kjenner henne fra de tre illustrerte bøkene, som er fraværende i bildeboka. (Se mer om språkakrobaten Pippi i f.eks. Edström 1992, Heldner 1992 og Bjorvand 1996.)

Som lesere opplever vi bildebokas Pippi som fysisk aktiv og full av spring på en annen måte enn den illustrerte barnebokas Pippi. Alle bevegelsene jeg har påpekt i denne artikkelen kan tyde på at Pippi er en "inkarnation av rörelse" også i bildeboka, men hun kan ikke lenger sies å fullt ut leve opp til Vivi Edströms karakteristikk av henne som"det arketypiska monstruösa barnet, det oövervinnerliga, med gigantiska krafter" (Edström 2007, 46). Pippis monstrøse karaktertrekk skapes i stor grad i møtet mellom Lindgrens ord og leserens fantasi, og en forskyvning av den funksjonelle tyngden fra ord til bilder fører til at Pippi framstår som en mindre ekstrem utgave av seg selv i bildeboka. Slikjeg ser det, er det ingen klare motsetninger mellom bildebokas Pippi og den illustrerte barnebokas Pippi, men bildebokas Pippi er en flatere person som beveger seg på andre måter og på et mer begrenset område enn den illustrerte barnebokas Pippi. Resultatet er - slik Lindgrens og Nymans intensjon sikkert også har vært - at bildeboka Känner du Pippi Långstrump? fungerer best for yngre lesere, eller som en introduksjon til den langt mer komplekse personen vi møter i de illustrerte barnebøkene. 
Biografisk information: Agnes-Margrethe Bjorvand är universitetslektor $i$ litteratur vid Universitetet i Agder, Institutt for nordisk og mediefag.

Kontakt: agnes-margrethe.bjorvand@uia.no.

\section{Bibliografi}

Bachtin, Mikhail. "Forms of time and of the chronotope in the novel: notes toward a historical poetics". I The dialogic imagination: four essays by M.M. Bakhtin. Red. Michael Holquist. Austin og London: University of Texas Press, 1981 [1937-1938], 84-258.

Bjorvand, Agnes-Margrethe. De sterke jentene: en studie av Astrid Lindgrens Pippi Långstrump og Ronja rövardotter. Hovedoppgave i nordisk litteratur. Oslo: Universitetet i Oslo, 1996.

Druker, Elina. Modernismens bilder: den moderna bilderboken i Norden. Diss., Stockholms universitet. Skrifter utgivna av Svenska barnboksinstitutet, 103. Göteborg \& Stockholm: Makadam, 2008.

Edström, Vivi. Astrid Lindgren: vildtoring och lägereld. Skrifter utgivna av Svenska barnboksinstitutet, 43. Stockholm: Rabén \& Sjögren, 1992.

Edström, Vivi. Det svänger om Astrid. Stockholm: Rabén \& Sjögren, 2007.

Forsell, Jacob, red. Astrids bilder. Stockholm: Bokförlaget Max Ström, 2006.

Hallberg, Kristin. “Litteraturvetenskapen och bilderboksforskningen. Tidskrift för litteraturvetenskap (1982) 3-4: 163-168.

Heldner, Christina. "I gränslandet mellan lingvistik och litteraturvetenskap: en analys av några språkliga drag i böckerna om Pippi Långstrump". I Modern litteraturteori och metod i barnlitteraturforskningen. Red. Maria Nikolajeva. Stockholm: Centrum för barnkulturforskning vid Stockholms universitet, 1992.

Jewitt, Carey og Gunther Kress, red. Multimodal literacy. New York: Peter Lang, 2003.

Kress, Gunther. Literacy in the new media age. London: Routledge, 2003.

Lindgren, Astrid. Ur-Pippi. Skrifter utgivna av Svenska barnboksinstitutet, 94. Stockholm: Rabén \& Sjögren, 2007 [1944].

Lindgren, Astrid og Björn Berg (ill.). Nya hyss av Emil i Lönneberga. Stockholm: Rabén \& Sjögren, 2006 [1966].

Lindgren, Astrid og Ingrid Nyman (ill.). Pippi Långstrump. Stockholm: Rabén \& Sjögren, 1945.

Lindgren, Astrid og Ingrid Nyman (ill.). Pippi Långstrump går ombord. Stockholm: Rabén \& Sjögren, 1946.

Lindgren, Astrid og Ingrid Nyman (ill.). Alla vi barn i Bullerbyn. Stockholm: Rabén \& Sjögren, 1947. 
Lindgren, Astrid og Ingrid Nyman (ill.). Känner du Pippi Långstrump?. Stockholm: Rabén \& Sjögren, 2007 [1947].

Lindgren, Astrid og Ingrid Nyman (ill.). Pippi Långstrump i Söderhavet. Stockholm: Rabén \& Sjögren, 1948.

Lindgren, Astrid og Ingrid Nyman (ill.). Mera om oss barn i Bullerbyn. Stockholm: Rabén \& Sjögren, 1949.

Lindgren, Astrid og Ingrid Nyman (ill.). Bara roligt i Bullerbyn. Stockholm: Rabén \& Sjögren, 1952.

Lindgren, Astrid og Eric Palmquist (ill.). Rasmus på luffen. Stockholm: Rabén \& Sjögren, 1956.

Lindgren, Astrid og Ilon Wikland (ill.). Barnen på Bråkmakargatan. Stockholm: Rabén \& Sjögren, 1958.

Lindgren, Astrid og Ilon Wikland (ill.). Vi på Saltkråkan. Stockholm: Rabén \& Sjögren, 1964.

Lindgren, Astrid og Ilon Wikland (ill.). Bröderna Lejonhjärta. Stockholm: Rabén \& Sjögren, 1973.

Lindgren, Astrid og Ilon Wikland (ill.). Ronja rövardotter. Stockholm: Rabén \& Sjögren, 1981.

McCloud, Scott. Understanding comics: the invisible art. New York: HarperPerennial, HarperCollins Publishers, 1994 [1993].

Nikolajeva, Maria. Children's literature comes of age: toward a new aesthetic.

New York og London: Garland Publishing, 1996.

Nikolajeva, Maria. Bilderbokens pusselbitar. Lund: Studentlitteratur, 2000.

Nikolajeva, Maria og Carole Scott. How picturebooks work. New York and Oxen: Routledge, 2001.

Note: This article is being published simultaneously in Barnboken - tidskrift för barnlitteraturforskning/Journal of Children's Literature Research and Nordic ChildLit Aesthetics/Barnelittercert forskningstidsskrift 